\title{
THE EXPRESSION OF THREAT IN JIHADIST PROPAGANDA
}

\section{A EXPRESSÁO DA AMEAÇA NA PROPAGANDA JIHADISTA}

\author{
Laura Ascone \\ Université Cergy-Pontoise, UCP, Cergy-Pontoise, França \\ Julien Longhi \\ Université Cergy-Pontoise, UCP, Cergy-Pontoise, França
}

\begin{abstract}
This study investigates the expression of threat in jihadist propaganda from a semantico-pragmatic perspective. The analysis was conducted on the two official online magazines published by Daesh: the English Dabiq, and the French Dar al-Islam. Since the two magazines address two different readerships, it was hypothesised that differences in the way threat is expressed would be identified. The combination of both qualitative and quantitative approaches has allowed us to examine quantitative results in a more detailed way and, therefore, to obtain more solid results. This study revealed that the two magazines differ in the way threat is verbalised.
\end{abstract}

Keywords: threat; extremism; ideology; discourse analysis; jihadism.

Resumo: Este estudo investiga a expressão "ameaça", na propaganda jihadista, dentro da perspectiva semântico-pragmática. A análise foi realizada nas duas revistas oficiais online publicadas por Daesh: o Dabiq inglês e o francês Dar al-Islam, uma vez que as duas revistas abordaram dois leitores diferentes, foi dito que as diferenças decorrem da forma como a ameaça é expressa e como ela é identificada. A combinação de abordagens qualitativas e quantitativas permitiu examinar resultados quantitativos de forma mais detalhada e, portanto, obter resultados mais sólidos. $\mathbf{O}$ estudo revelou que as duas revistas diferem na forma como a ameaça é verbalizada.

Palavras-chave: ameaça; extremismo; ideologia; análise do discurso; jihadismo.

\section{Introduction}

The recent terrorist attacks by Daesh in Western countries have led researchers and experts to examine the islamisation of radicalism (ROY, 2016). Different studies have been conducted on the psychosociological contexts that may lead someone to adhere to the jihadist ideology (BENSLAMA, 2016; KHOSROKHAVAR, 2014), as well as on the role played by the Internet in the radicalisation process (VON BEHR, 2013). This analysis investigates the language employed by Daesh in its propaganda. 
More precisely, it examines both the form and the content of threat in the two official jihadist magazines: Dabiq and Dar al-Islam. We consider threat as "a statement in which you tell someone that you will cause them harm or trouble if they do not do what you want" (from Longman Dictionary of Contemporary English). From a linguistic perspective, threat is a complex speech act. Following Searle's (1979) speech act classification, Weill (1993) considers threat as an assertive act, where the proposition is expressed in a precise and vigorous way, but also as a directive act, since the speaker aims at leading his interlocutor to act even against his (of the interlocutor) intention. He classifies threat also as a promissive act, where the speaker is committed to undertaking a certain action, as well as an expressive act, caused by rancour or hostility. However, he does not consider threat as a declarative act because the speaker does not intend to fulfil his part of the deal; he only wants his interlocutor to act. Pragmatics and, more specifically, Searle's speech act theory as well as Weill's description of threat, constituted the basis of our study. The corpus analysis conducted with the software Tropes allowed us to take into account the semantic dimension too. After having presented the corpus and the methodology adopted, we will examine the rhetorical pattern characterising jihadist discourse. To conclude, the different types of threat will be investigated. Since the two magazines address different readers and countries, it was hypothesised that these two magazines would differ in the themes tackled as well as in the rhetorical strategies adopted.

\section{The corpus and methodology}

This analysis was conducted on the two official magazines published online by Daesh and, more precisely, by Al Hayat Media Center: Dabiq, published in English, and Dar al-Islam, published in French. Even though the two magazines are published on the web, they are presented as paper magazines; each number of both Dabiq and Dar al-Islam includes, for instance, tables of content, photo coverage, interviews, etc. Dabiq, whose first number was published on July 2014, only some days after the Caliphate was re-established, addresses any non-Arabic sympathiser. On the other hand, Dar al-Islam, which is not a translation of the English magazine, was published for the first time on December 2014, and addresses French readers only. This distinction leads us to hypothesise that the two magazines differ both in the content and the form of the message. However, what Dabiq and Dar al-Islam have in common is that they address a readership 
that has already adhered to the jihadist ideology. Therefore, their goal is not to persuade the reader to adopt a jihadist vision of the world. Rather, they aim at reinforcing the reader's adhesion as well as leading him/her to act in the name of the jihadist ideology. To date, Dabiq counts fifteen numbers, whereas Dar al-Islam counts nine numbers only.

In order to analyse the way threat is expressed, a quanti-qualitative approach was adopted (cf. GARRIC; LONGHI, 2012; RASTIER, 2011). More precisely, this iterative approach was composed of four stages. A first qualitative analysis of the jihadist ideology, the radicalisation process, and the linguistic characteristics of hate speech has been essential to the understanding of the jihadist discourse as well as to the advancement of our first hypotheses. The second stage corresponded to a quantitative analysis whose goal was to verify the validity of our hypotheses: the two corpora ${ }^{1}$ (Dabiq: 377,450 words, and Dar al-Islam: 229,762 words) were then examined with the software Tropes, which allows to investigate a text from a semantic perspective. More precisely, based on a pre-established lexicon, the software identifies the themes tackled in the text, and shows how these themes are linked to one another. The most frequent themes in the two magazines are religion and conflict. However, in order to study the way threat is expressed in the corpus, a deeper qualitative analysis was conducted on the themes feeling, for the English corpus, and sentiment, for the French one (third stage). In other terms, the quantitative analysis has constituted the basis for a qualitative study, which was then conducted only on the expressions conveying threat. The nine issues of the French magazine, which is smaller in size, count 114 threatening expressions. Therefore, in order to conduct the analysis on comparable-size corpora, and to contrast the results obtained, the study was conducted on the same number of propositions conveying threat in French and English. Particular attention was paid to the link between cause and threat in order to see whether the expression of threat is preceded, followed or independent from the expression of its cause. The content of the different expressions was investigated as well. Finally, a last quantitative analysis was conducted in order to test the hypotheses and results issued by the qualitative study (fourth stage). The combination and alternation of both quantitative and qualitative approaches allowed us to examine Daesh's discourse in relation to the context in which it is produced (VALETTE; RASTIER, 2006). Since Dabiq and Dar al-Islam address different readerships, it was hypothesised that the two magazines

\footnotetext{
${ }^{1}$ The nine issues of the French Dar al-Islam count 229,762 words, whereas the fourteen issues of the English Dabiq (this study was conducted before the fifteenth issue was published) count 377,450 words.
} 
would differ in both content and form.

Before examining the characteristics of the propositions conveying threat in both Dabiq and Dar al-Islam, we will show the role played by threat in the rhetorical pattern characterising jihadist discourse.

\section{The rhetorical pattern of jihadist discourse}

The study conducted on the persuasive and threatening discourse peculiar to the jihadist propaganda (ASCONE, 2017) has shown that it is difficult, if not impossible, to analyse persuasion independently from threat. This is due to the intrinsic structure of hate speech, which was defined as a complex speech act (CHEVALIER; CHANAY, 2009). Hate speech is composed of three dimensions and functions: an assertive function, an expressive one, and a directive one. Asserting an insult, for example, corresponds to the attribution of negative characteristics to someone. For instance, in the jihadist dichotomous vision, where the extremist group is opposed to an other, this other is presented as "infidel" and "hypocrite". Through the expressive function, the insulter shows his/her addressee a hostile attitude. By rejecting any diversity, jihadists clearly show to the other that neither dialogue or mediation are possible. Defeating the other is the only solution. The attacks, whether verbal or non-verbal attacks, by Daesh aim at leading Western countries to react (directive function). This reaction may have negative consequences for the jihadist group, as it often implies attacks by the Coalition. However, the jihadists may take advantage of this: these reactions are presented as evidence of the fact that the Muslim community is a victim, which would justify any violent action against Western countries. Furthermore, the insulter places him/herself in a position that is higher and more powerful than the insulted person's (GOFFMAN, 1959). Because of these different positions, a threatening message may be perceived as persuasive by any individual sharing the insulter's point of view. The either persuasive or threatening interpretation of a same utterance depends then on the addressee's references, which include his/her universe of beliefs and cultural background.

As stated before, Dabiq and Dar al-Islam aims at leading the readership to act in the name of the jihadist ideology. In other terms, the speaker's goal is to manipulate the reader's behaviour by imposing obligations and/ or prohibitions, which are often presented as religious indications. Like in the epideictic discourse, the speaker presents himself as his readership's educator (PERELMAN; OLBRECHTS-TYTECA, 1988). In this case, the 
speaker makes religious texts accessible to his readers. The reader will tend to perceive the author as a legitimate and reliable source. Therefore, he will feel obliged to respect any indication that he is given. This shows that the way the message is verbalised and conveyed is crucial to the adherence to a certain ideology. The speaker, in this case the author, may establish an ideology and, therefore, an ideological discourse starting from a statement or an opinion. By referring to texts and/or events that are official and reliable to the reader's eyes (past), the author reinforces and makes incontestable the statement, or the opinion, on which he is building his discourse. This way, the opinion's subjectivity turns into objectivity, which makes a simple opinion a universal statement. A statement like "Western countries are not Muslim countries", or an opinion such as "Islam should be the only religion to be accepted", will then be presented as an established and shared truth: "those who do not believe in Allah are disbelievers". The modal should, which characterises the expression of opinions, has been replaced with the present tense (are), which is peculiar to the expression of general truths. Once these general truths have been established, the author builds on them obligations and prohibitions, whose aim is to lead the reader to act (present). Action is then present as what allows to follow and respect these general truths, and to reach a goal, in this case Islam's supremacy (future). This process is defined by Sarfati (2011) as a "processus d'idéologisation" (in English, ideologising process). According to him, ideological discourse does not exist; what exists is an ideological use of a certain discourse. In other terms, it is the ideologising process that makes a discourse ideological (p. 157) ${ }^{2}$.

Furthermore, in order to incite the readership to act, the author presents attracting rewards that can only be obtained by following the obligations and prohibitions imposed. On the contrary, not respecting them implies negative consequences for the reader. This is then a first type of threat: the threat against the Muslim community itself, which is often linked to obligations and prohibitions. Furthermore, the author aims at leading his readership to act against the other. Therefore, many obligations imply violent actions against the jihadist group's enemy. In the following section, the different types of threat identified in the corpus will be investigated more in detail.

In jihadist discourse, not only can we find the other's dehumanisation (MCCAULEY; MOSKALENKO, 2008), we can find the valorisation of Daesh's membership too. This aspect has a persuasive function. Contrary

\footnotetext{
${ }^{2}$ « Nous tenons qu'il n'y a pas de discours idéologique, mais seulement des usages idéologiques de certains discours. Autrement dit un discours ne devient idéologique ou ne reçoit le statut d'idéologie qu'au terme d'un processus d'idéologisation " (SARFATI, 2011, p. 157).
} 
to rewards, persuasion is presented as something positive and valorising to the reader's eyes, but that does not depend on respecting obligations and/ or prohibitions. Furthermore, guilty and victimisation feelings are elicited by the author in order to fuel hatred and violent action against the enemy. More precisely, the speaker aims at eliciting guilt in Western Muslims towards Middle-Eastern Muslims, who are attacked from the Coalition. This way, the reader will feel obliged to act against the West in order to help his brothers and sisters in Syria and Iraq. As far as victimisation is concerned, the Muslim community is presented as victim of the West, which, as a consequence, needs to be fought.

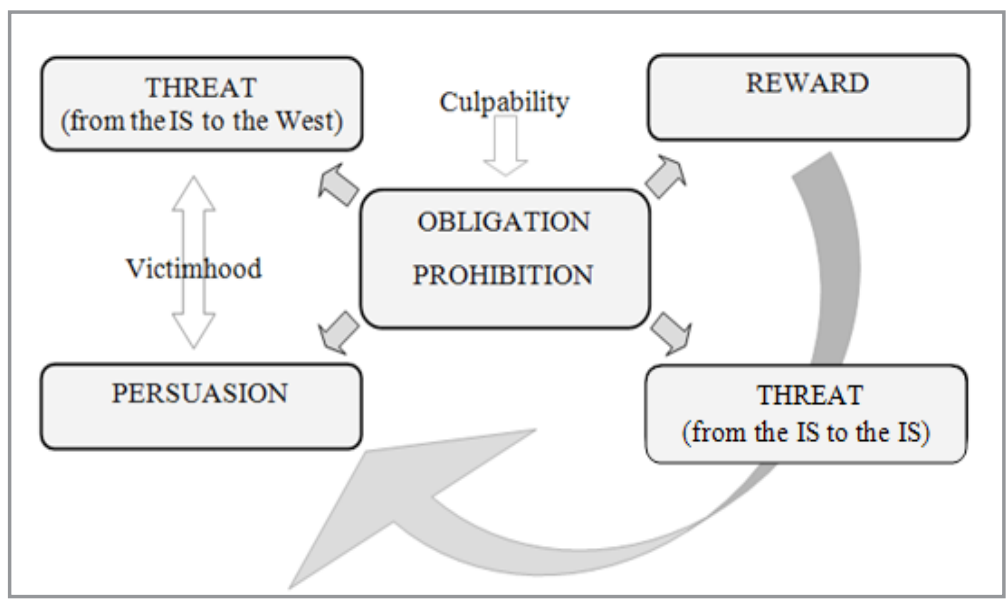

Figure 1: jihadist discourse's rhetorical pattern

Source: illustration by the authors

Figure 1 shows the rhetorical pattern of jihadist discourse. Since Dabiq and Dar al-Islam aim at manipulating the reader's behaviour, jihadist propaganda is based on obligations and prohibitions. Rewards as well as guilty feelings towards the Muslims living in the Middle-East aim at leading the reader to respect these indications. On the other hand, not respecting them means facing negative consequences. Threat may then be expressed against the members of Daesh themselves and, more in general, against any Muslim. Obligations are also exploited to impose the readership a hostile and violent attitude against Western countries, which is justified by the feeling of victimisation. Fighting against the Muslims' enemy is perceived 
by jihadists as a heroic and valorising action, and therefore, a persuasive one.

The sentence "Jihad is necessary to obtain Allah's forgiveness" presents an obligation ("it is necessary") and a reward if the obligation is respected ("to obtain Allah's forgiveness"). However, this sentence expresses more than an obligation and a reward. Jihad, which is interpreted as persuasive by jihadists, tends to be associated with terrorist attacks and, as a consequence, it will be perceived as threatening by Western countries. Furthermore, this sentence implies that if the obligation is not respected, the individual will not obtain Allah's forgiveness. In other terms, this sentence indirectly expresses a threat against the readership.

In the following section, a more detailed analysis of propositions conveying threat will be presented. The goal is to investigate the different types of threat expressed in Dabiq and Dar al-Islam, and to compare English and French discourses.

\section{Threatening jihadist discourse}

As already stated in the two previous sections, different types of threat have been identified in jihadist discourse: on the one hand threat against enemies, and on the other hand threat against Muslims. However, analysing these expressions more in detail, it has been possible to identify four different classes of threat: direct threat against Muslims, direct threat against enemies, the description of violent actions, and the incitation to commit violent actions against the enemy. As far as the direct threat is concerned, we consider direct any threatening expression that is addressed to an individual, a group of people, or a third person or group. Contrary to descriptions of violent actions, direct threats express as intention to inflict pain or damage. These expressions are then characterised by the use of verbs in the future forms, like Example 1 and Example 2 show. Even though Daesh's enemies are not supposed to read the magazine, direct threats against them were identified. The classification of direct threats (against Muslims as well as against enemies) was based on whether the expression referred to a past event (description) or to a future action (direct threat). The two following tables show the frequency of the four different types of threat, as well as their structures: cause-threat (C-T), threat-cause (T-C), threat (T), and cause (C). 


\begin{tabular}{|c|c|c|c|c|c|}
\hline Dabiq & $\begin{array}{c}\text { direct } \\
\text { enemies }\end{array}$ & $\begin{array}{c}\text { direct } \\
\text { Muslims }\end{array}$ & description & incitation & Tot. \\
\hline T-C & 4 & 7 & 34 & 0 & 45 \\
\hline C-T & 4 & 12 & 29 & 0 & 45 \\
\hline T & 8 & 4 & 12 & 0 & 24 \\
\hline C & 0 & 0 & 0 & 0 & 0 \\
\hline Tot. & 16 & 23 & 75 & 0 & 114 \\
\hline
\end{tabular}

Table 1: frequency of the four types of threat and their structures in Dabiq Source: illustration by the authors

\begin{tabular}{|c|c|c|c|c|c|}
\hline Dar al-Islam & $\begin{array}{c}\text { direct } \\
\text { enemies }\end{array}$ & $\begin{array}{c}\text { direct } \\
\text { Muslims }\end{array}$ & description & incitation & Tot. \\
\hline M-T & 14 & 2 & 26 & 4 & 46 \\
\hline T-M & 5 & 5 & 31 & 1 & 42 \\
\hline T & 6 & 1 & 16 & 2 & 25 \\
\hline C & 0 & 0 & 1 & 0 & 1 \\
\hline Tot. & 25 & 8 & 74 & 7 & 114 \\
\hline
\end{tabular}

Table 2: frequency of the four types of threat and their structures in Dar al-Islam Source: illustration by the authors

As stated before, the distinction between threat's expression and description has been based on their linguistic characteristics. When the sentences present a verb either in the simple present (general truth that is supposed to be shared by the speaker and his/her addressee) or in any past tense (events' description), it has been classified as a description. On the contrary, when the sentence presents either a future or an imperative verb, it has been considered as a direct threat.

Even though the total frequency of the four structures (M-T, T-C, T, and $\mathrm{C}$ ) is almost identical in the two magazines, their distributions vary on the type of threat that is expressed. 


\section{Direct threats against enemies and Muslims}

Dabiq and Dar al-Islam mainly differ in the number of expressions conveying threat against the enemies and against Muslims. In the English magazine, threats against Muslims (23 occurrences) are more frequent than threats against enemies (16 occurrences). On the contrary, the French magazine presents the opposite pattern. Threats against enemies (25) are far more frequent than threats against Muslims (8). This difference indicates that the French magazine focuses more on the other and on the violent action against it, whereas the English magazine focuses its discourse on the way a good Muslim should behave. Direct threat against Muslims is the negative consequence of not respecting the obligations and/or prohibitions that are imposed on the readership by the author. This difference between the two magazines is likely due to the fact that the English one addresses any non-Arabic sympathiser; discourse and language have to be modulated and adapted to a very wide readership. The French magazine, on the other hand, addresses French speakers only and, therefore, a much more restricted readership. As far as the direct threat's structure is concerned, differences were identified in the two magazines. The English discourse tends to favour the cause-threat structure (Example 1), whereas the French one usually expresses the threat followed by its cause (threat-cause structure) (Example 2).

1. "As for the Muslim students who use this same pretence now to continue abandoning the obligation of the era, then they should know that their hijrah from darul-kufr to darul-Islam and jihad are more obligatory and urgent then spending an unknown number of years studying while exposed to doubts and desires that will destroy their religion and thus end for themselves any possible future of jihad" (Dabiq, $\left.\mathrm{n}^{\circ} 3\right)$.

In this example, threat against Muslims ("that will destroy their religion and thus for themselves any possible future of jihad") is the consequence of not respecting the two obligations imposed: jihad and hijrah. The use of the terms obligation and obligatory makes this link explicit. As far as threat is concerned, it is the verb at the future form and the verb destroy that make this sentence threatening. Furthermore, the author presents a consequence that would have a negative impact not only on the reader ("thus end for themselves any possible future of jihad"), but also for the Muslim community ("that will destroy their religion"). This strategy aims at giving the reader the impression to have a responsibility and an important role within the Muslim community (SIFAOUI, 2010). 
2. "Je vais jeter leeffroi dans les cœurs des mécréants" (Dar al-Islam, n 9).

("I will elicit fear in the disbelievers' hearts").

Example 2 shows a direct threat against the enemy (mécréants, "disbelievers"). Like in Example 1, it is the verb at the future form and the term effroi ("fear") that give the sentence a threatening tone. As far as the cause is concerned, it is conveyed with the term mécréants ("disbelievers"). In the jihadist ideology, disbelievers are among the main Islam's enemies; therefore, they need to be eliminated.

\section{Description of threatening actions}

Contrary to the expression of direct threat, the description of threatening actions is characterised by the presence of verbs in the simple present tense, which express a shared truth, or in any past tense, used to describe events. Even though the number of occurrences in the two magazines is almost identical (75 occurrences in Dabiq, and 74 occurrences in Dar al-Islam), the two languages differ in the type of structure that is used. Contrary to what was stated concerning the expressions conveying direct threats, English tends to favour the threat-cause structure (Example 3), whereas in the French corpus, the cause-threat structure is privileged (Example 4).

3."Humiliation and degradation were placed upon those who oppose my order" (Dabiq, $\mathrm{n}^{\circ} 3$ ).

This example is an excerpt of a speech by the Prophet; therefore, the possessive determiner my refers to the Prophet. The presentation of a universal order and of a incontestable divinity is proper to the epideictic discourse. In the jihadist propaganda, these two notions aim at legitimising any indication imposed to the readership as well as any violent action led against the enemy. They also have the objective to manipulate the reader's behaviour, by leading him/her to follow both the obligations and prohibitions expressed by the author. Like Example 1, this example shows the link between obligation ("order"), and more particularly, the nonrespect of obligations ("who oppose my order), and threat ("humiliation and degradation"). Furthermore, the sentence presents a past tense verb (description of events) and a simple present verb (general truth shared by the author and the reader). This combination leads the reader to perceive the sentence as a warning and, in a more indirect way, as a threat. 
4. Ibn Taymiyyah : «Celui qui n'adore pas Allâh par orgueil n'est pas musulman et celui qui adore avec Allâh d'autre que Lui n'est pas musulman " (Dar al-Islam, n 3).

(Ibn Taymiyyah: "The one who does not worship Allah because of pride, is not Muslim, and the one who worship Allah and other than Him, is not Muslim").

Example 4 is a quote by Ibn Taymiyyah, one of the most extremist medieval savants, and one of the most recurrent references in the jihadist propaganda. The verbs in the present tense indicates a general truth that is shared by the author and the reader. As far as threat is concerned, it is expressed by n'est pas musulman ("is not Muslim"). For any individual not sharing the jihadist point of view, this is a simple statement. However, for those who have adhered to jihadism, not being Muslim is perceived as something negative that needs to be eliminated. The interpretation depends on the interlocutor' references, which include his/her universe of beliefs and cultural background. De Bonis (2015) and Adonis (2015) mention the double interpretation of violence. Violence, whether it is verbal or nonverbal, is not perceived as such because it is seen as an action led in the name of a noble and just cause. In the jihadist vision of the world, violence represents the triumph of Islam and of Allah's will.

\section{Inciting to violent action against the enemy}

An additional element that shows that the French discourse is more violent than the English one, is the presence of expressions inciting to commit violent actions against the other. This category is completely absent in Dabiq. On the contrary, the French corpus presents 8 sentences inciting the readership to act against the enemy (Example 5).

5. «Déclenche ta ceinture d'explosifs au milieu d'eux, tires sur leurs soldats, incites-les à ne pas combattre les mouwahid, les moujâhidîn et répand le découragement dans leur rang, ensuite si tu ne peux pas prendre le dessus sur eux dans leur terre pour appliquer la charîah et faire allégeance au calife ouvertement et que tu ne peux les attaquer dans leur terre et les tuer pour défendre le califat, alors émigre vers la terre du califat car elle est la meilleur des terres vers laquelle tu peux faire hijrah vers Allâh " (Dar al-Islam, $\mathrm{n}^{\circ}$ 5).

"Make your belt explode among them, shoot their soldiers, incite them not to fight against the mouwahid, the moujahidin, and spread discouragement among them. Then, if you cannot gain the upper hand in their lands to establish sharia, nor make openly allegiance to the caliph, nor attack them in their lands, nor kill them to defend the caliphate, then emigrate to the land of the caliphate because it is the best land to which you can do the hijrah towards Allah". 
The series of imperatives in Example 5 shows that the author is inciting his reader to follow these indications. He is then inciting the reader to commit violent actions against the enemy. The use of possessive adjectives like leurs soldats ("their soldiers") aims at underlying the distinction between the community both the author and the reader belong to, and the other. This distinction reflects the dichotomous vision Daesh has: good vs. bad, licit vs. illicit, believer vs. misbeliever, etc. To the eyes of a young person looking for certainties and stability, this simplistic vision of the world may appear simple to accept and adopt and, as a consequence, persuasive (BENSLAMA, 2016). Like in Example 1, the author wants to give his readers the impression to have an active and determining role within the jihadist community. In Example 1, the destruction of Islam is presented as depending on the reader's action or non-action. In Example 5, on the other hand, acting against the enemy has a defensive and heroic function (les tuer pour defender le califat, "kill them to defend the caliphate"). The reader is then incited to act against the enemy so that the caliphate will not be defeated by the West. Furthermore, the verb defendre ("defend") implies that the Muslim community is under attack and that it is a victim of the West. The feeling of guilt is often exploited by Daesh to justify and incite to violent action against the enemy.

\section{Conclusion}

Starting from the rhetorical pattern characterising the jihadist propaganda, where threat represents only a facet of the jihadist discourse, we have examined both the content and form of propositions conveying threat. This analysis has confirmed the hypothesis that, since Dabiq and Dar al-Islam do not address the same readership, the two magazines present different discourses and different types of threat. Four kinds of threat were identified: direct threat against enemies, direct threat against Muslims, the description of threatening events, and the incitement to commit violent action against the enemy. The English discourse tends to focus on the Muslim community and on the way a good Muslim should behave; this tendency was shown by the frequent expressions of threat against Muslims. This type of intimidation is often linked to the non-respect of obligations and/or prohibitions that the author imposes to his reader. On the contrary, the French magazine presents a higher number of threats against the enemy. This shows that Dar al-Islam focuses more on the other, against which it is necessary to fight. The French discourse is therefore more violent than the English one. The presence of only French expressions inciting the reader to act against the West is evidence of the violent dimension peculiar to the French magazine. Differences in the threat's structures were identified as well. 
This study has shown that jihadist propaganda is modulated and adapted according to the readership to which it addresses. Furthermore, threat is not something homogeneous; it contains different nuances that need to be taken into account in order to establish a counter-narrative able to deconstruct jihadist discourse and, as a consequence, to counter the islamisation of radicalism.

The differences that were identified in Dabiq and Dar al-Islam raise two questions: is the same ideology expressed in two different ways, or do the two magazines convey two different ideologies? As this study has shown, Dabiq focuses on the behaviour a good Muslims should adopt (which would correspond to the personal/interior jihad), whereas Dar al-Islam focuses on the fight against the other (i.e. defensive/external jihad). This might lead to the conclusion that the two magazines convey two distinct ideologies. However, since they both focus on jihad, it might be argued that they focus on two different aspects of a same ideology. As far as the second question is concerned, are these differences in Dabiq and Dar al-Islam evidence of the fact that the context in which a message is produced influences the message itself? Or does Daesh consciously adapt its discourse to the context(s) in which the message will be conveyed, in order to have a major impact on the readership? According to Valette and Rastier (2006), the differences between the two magazines would be due to the context (i.e. both language and culture) in which the message is spread. However, a deeper analysis conducted on this specific propaganda would allow us to characterise this particular aspect of the jihadist propaganda.

\section{References}

ADONIS. Violence et Islam. Editions du Seuil, 2015.

ASCONE, L. Menace et persuasion dans le discours extrémiste. Retrieved from : $<$ https://cdradical.hypotheses.org/467>. Access in : 01 dec. 2017.

BENSLAMA, F. Un furieux désir de sacrifice: le surmusulman. Paris : Edition du Seuil, 2016.

CHEVALIER, Y.; DE CHANAY, H. C. Savoir être insulteur, ou les marqueurs verbaux et non verbaux de l'insulte: quelques exemples de "pédé". In: Les insultes en français: de la recherche fondamentale à ses applications, 2009. p. 45-74.

DE BONIS, M. La strategia della paura. Limes, n. 11, 2015. 
GARRIC, N.; LONGHI, J. L'analyse de corpus face à l'hétérogénéité des données: d'une difficulté méthodologique à une nécessité épistémologique. Langages, n. 3, p. 3-11, 2012.

GOFFMAN, E. The Presentation of Self in Everyday Life. New York: Doubleday, 1959.

KHOSROKHAVAR, F. Radicalisation. Paris: Editions de la maison des sciences de l'homme, 2014.

MCCAULEY, C.; MOSKALENKO, S. Mechanisms of political radicalization: pathways toward terrorism. Terrorism and Political Violence, n. 20, v. 3, p. 415-433, 2008.

PERELMAN, C.; OLBRECHTS-TYTECA, L. Traité de l'argumentation. Bruxelles: Edition de l'Université libre de Bruxelles, 1988.

RASTIER, F. La mesure et le grain: sémantique de corpus. Champion; diff. Slatkine, 2011.

ROY, O. Le djihad et la mort. Le Seuil, 2016.

SARFATI, G. Analyse du discours et sens commun: institutions de sens, communautés de sens, doxa, idéologie. Matériaux philosophiques pour l'analyse du discours. Besançon (Presses universitaires de Franche-Comté), 2011, p. 139-173.

SEARLE, J. R. Expression and meaning: Studies in the theories of speech acts. Cambridge, 1979.

SIFAOUI, M. Pourquoi l'islamisme séduit-il?. Paris: Armand Colin, 2011.

VALETTE, M.; RASTIER, F. Prévenir le racisme et la xénophobie: propositions de linguistes. Langues modernes, n. 100, v. 2, 2006.

VON BEHR, I. Radicalisation in the digital era: The use of the Internet in 15 cases of terrorism and extremism, 2013.

WEILL, I. La menace comme acte de langage: etude diachronique de quelques formules de français. Linx, 28(1), p. 85-105, 1993.

Laura Ascone <laura.ascone@etu.u-cergy.fr> Julien Longhi <julien.longhi@u-cergy.fr>

Recebido: 28/08/2017

Aceito: 04/10/2017 